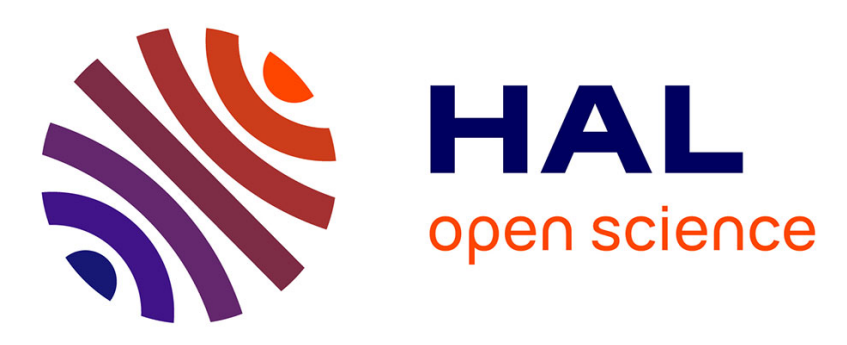

\title{
The birth of the political economy or the economy in the heart of politics
}

\author{
Jacques Fontanel, Jean-Paul Hébert, Ivan Samson
}

\section{To cite this version:}

Jacques Fontanel, Jean-Paul Hébert, Ivan Samson. The birth of the political economy or the economy in the heart of politics: Mercantilism. Defence and Peace Economics, 2008, War and Peace Issues in the History of Economic Thought, 19 (5), pp.331-338. 10.1080/10242690802354279 . hal-02059663

\section{HAL Id: hal-02059663 \\ https://hal.univ-grenoble-alpes.fr/hal-02059663}

Submitted on 6 Mar 2019

HAL is a multi-disciplinary open access archive for the deposit and dissemination of scientific research documents, whether they are published or not. The documents may come from teaching and research institutions in France or abroad, or from public or private research centers.
L'archive ouverte pluridisciplinaire HAL, est destinée au dépôt et à la diffusion de documents scientifiques de niveau recherche, publiés ou non, émanant des établissements d'enseignement et de recherche français ou étrangers, des laboratoires publics ou privés. 


\title{
The birth of the political economy or the economy in the heart of politics: Mercantilism
}

\author{
Jacques Fontanel, Jean-Paul Hébert, Ivan Samson
}

Mercantilist theories were expressed both in doctrinal works and by concrete measures of economic policy. Mercantilism did not produce a single and immutable thought; its analyses, if not its principles, have appreciably changed over time and space. Today, some divergences still remain about the interpretation of this school, particularly with regard to the importance of the relationship between power and economic development; but this first corpus of economic thought was built through two centuries of analyses on the relationship between the power of the state and national wealth. In spite of its considerable influence from the Renaissance to the emergence of the Physiocrat and Classical schools, mercantilism was never set up as a formalised theory. However, some of its principles have remained alive through economic policies of the 20th century, before that the process of globalisation achieves the dominance of liberalism, which sustainability is however not granted.

By centralising power, monarchies from the 15th to the 18th century had set up legal and administrative structures on which the merchants and the bourgeoisie established their wealth and power. Conflicts between European powers were mainly connected with the colonial conquest, disputes of trade monopolies or even the control of fishing zones (between England and Holland, in particular). The idea of war in the broad sense, i.e. implying the military but also economic forces, was already very present throughout the mercantilist theory. The economy was conceived like an instrument for state power. Wealth was first in the service of power, since the Prince needed to have available stocks of resources to achieve his political objectives. Then the principles of the mercantilists aimed at guiding the foreign policy of Prince. The economic and political objectives were strongly interdependent.

In this context, mercantilists' analysis was based on a syllogism (Coulomb, 1998, pp. 37-77). First an increase in the national wealth leads to an improvement of the power of the Prince and vice versa. Second if this increase in wealth results from foreign trade ceteris paribus, it is only possible to the detriment of other states in terms of wealth and thus power, for. Trade serves politics. Third a conflict between the objectives of state power and wealth is inconceivable. Thus the power was the main objective of the state policy, even if people's welfare was also taken into consideration. ${ }^{1}$

Mercantilism is not a structured as a school of thought; it took in fact rather different forms depending on countries and periods, though the idea of a necessary relation between the power of the Prince and economic development was rather commonly shared. Nevertheless mercantilist policies in European countries were rather heterogeneous and produced divergent economic results on national economies, leading to modify the international hierarchy of countries.

This article is organised as follows. Section 1 presents the main analyses of mercantilists. Section 2 highlights their implementation in European economic policies from the 15th to the 18 th century.

\section{Trade balance, war treasure, industrial competition and populationism, major weapons of the power of the Prince}

\footnotetext{
${ }^{1}$ Machiavelli already considered at the end of the 15th century that the power of the Prince is not an end in itself. The people intend to have a sufficient welfare to respect the Prince.
} 
With the constitution of nation states, financial needs of European monarchies considerably increased due to the rise of permanent mercenary armies and new, expensive military techniques. The dominant idea then was that the power of the Prince required the availability of sufficient monetary resources, notably to finance war. For Colbert in France or John Locke in England, only the constitution of an important war treasure could ensure the protection of national wealth but also the ability to threaten and militarily dominate a competing state.

For Antoine de Montchrestien (1615), "money is the sinews of war." The possession of a stock of precious metals was considered as essential in order to procure the desired goods, notably weapons. This analysis was disputed by Thomas Mun (1664), who considered that the Prince should have at his disposal not only an important treasure, but also the required goods. He thus discussed about the future "law of markets" while questioning the adequacy, at a determined period, between supply and demand. The availability of money may not be sufficient in case of an unexpected conflict outbreak.

English mercantilists insist on the necessity of industrial production and exports (Coulomb, 1998). For Charles Davenant, the interest of the Prince supposes an aggressive trade policy, as gold could only be acquired through trade. However, the development of trade is also needed to remain strong. "Can a nation be safe without strength? And is power to be compared and secured but by riches? And can a country become rich any way, but by the help of a well-managed and extended traffick? What has enable England to support this expensive war so long, but the great wealth which for 30 years has been flowing into us from our commerce abroad?" (Davenant, 1696)

A country should therefore aim at developing a trade surplus, necessary both for economic and political objectives. Thomas Mun thus glorified the role of foreign trade: "Behold then, the true form and work of foreign Trade, which is, The great Revenue of the King, the honour of the Kingdom, The Noble profession of the Merchant, The school of our Arts, The supply of our wants, The employment of our poor, The improvement of our Lands, The Nursery of our Mariners, The walls [i.e. ships] of the Kingdom, The means of our Treasure, The Sinews of our Wars, The terror of our Enemies. For all which great and weighty reasons, do so many well governed States highly countenance the profession, and carefully cherish the action, not only with Policy to increase it, but also with power to protect it from all foreign injuries: because they know it is a Principle in Reason of State to maintain and defend that which doth Support them and their estates." (Mun, 1664, p. 95)

Mercantilist policies were implemented when nations were being built as political entities, a period marked by the exacerbation of nationalist feelings, with the will to weaken other countries even to the detriment of a country's welfare (what has later been highlighted by the game theory), and consequently with the long-term research of economic self-sufficiency. Francis Bacon (1625) associated the trade balance with "the balance of power." According to him, the policy of England should aim at developing its national power along with trade. This increase in power and national treasure was made to the detriment of rival economies.

For Josiah Child, "all riches and Power, as well as private families, consists in comparison." (Child, 1681, p. 30) An exchange that enriches both parts was not desirable, if it did not improve the power of the nation relative to that of its exchange partner. Mercantilism presented a static conception of the economy, the world economic resources being supposed fixed. The international economic relations are therefore characterised by an economic and military competition for foreign markets and resources.

The mercantilist policy was then based on the use of import restriction, export promotion and other measures of trade wars (Davenant, 1696, p. 96). Josiah Child thus defended the Navigation Acts: "I am of [the] opinion that in relation to Trade, Shipping, Profit and Power, it is one of the choicest and most prudent Acts that ever was made in England, and without 
which we had not now been owners of one half of the Shipping, nor trade, nor Employed one half of the Sea-men which we do at present." (Child, 1693, p. 124).

The control of trade roads was also recommended to facilitate exports and secure the preferential colonial trade.

However some reservations were then made concerning wars, as they involved expenditures outside the country and therefore gold outflows (Clément, 1695, p. 371). This negative effect does not appear in the wars engaged at the borders of the kingdom or on the seas (Mun, 1664, p. 99). Then some wars of conquest were condemned as unjustified. Their reason is not the imperative defence of national rights, but the pride and greed of the Prince (Mun, 1664, p.128).

"In a Country not furnished with Mines there are but two ways of growing Rich, either Conquest, or Commerce. By the first the Romans made themselves Masters of the Riches of the World; but I think that in our present circumstances, no Body is vain enough to entertain a Thought of our reaping the Profits of the World with our Swords, and making the Spoil and Tribute of Vanquished Nations, the Fund for the supply of the Charges of the Government, with an overplus for the wants, and equally craving Luxury, and fashionable Vanity of the People. Commerce therefore is the only way left to us, either for Riches or Subsistence, for this the advantages of our Situation, as well as the Industry and Inclination of our People, bold and skilful at Sea, do Naturally fit us (...)" (Locke, 1691, p. 63)

In France, if Jean Bodin considered that a war against an external enemy was useful for internal peace, Antoine de Montchrestien underlined the importance of economic prosperity in order to maintain a strategic superiority. Locke (1696, p. 173) notes: "If any of our Neighbours have in much greater abundance than we (...) 1- They can maintain a greater force. 2- They can tempt away our people, by greater wages, to serve them by Land or Sea or in any Labour. 3- They can command the Markets and thereby break our Trade, and make us poor. 4- They can on any occasion ingross Naval and Warlike Sotres, and thereby endanger us."

However the extent of foreign trade needs a solid military force, both for aggressive and deterring aims. Trade and military interests are mutually reinforcing.

The French "Colbertist" trade policy was characterised by the prohibition of raw material exports, the promotion of manufactured goods exports and import restrictions. The state policy focused on developing the French industry to sustain the international competition thanks to protectionism, financial aids, privileges or the creation of state manufactures. The suppression of tolls and the development of routes favoured the rise of domestic trade. For Colbert, the liberalisation of domestic trade as well as the development of exports should mobilise productive forces and increase national wealth, the ultimate aim being to reinforce the power of the Prince and national safety. ${ }^{2}$

The mercantilist thought contains a first expression of the concepts of arms race and economic war: if the enemy is poorer or economically less advanced, the increase in military efforts exhausts it more quickly, thus increases its vulnerability (Fontanel, 2005, pp. 480 et sqq.). Moreover all citizens work in favour of their Prince, in the same spirit as Sun Zi's analyses. Thus the merchants can be used as intelligence agents while bringing priceless information to the nation on the economy and resources of the nation.

"Salomon saith, that wisdome is better then the weapons of warre, therefore a Merchant can in times of warres with forraigne Princes, better direct how to weaken his enemies, in course of their traffike, and prejudice them in the point of their profit, and cross their designed intentions, for provision of warfare, more then the best States-man can doe by open hostility. (...) In concluding of a peace, or in the making of leagues, and amity with forraigne Princes,

\footnotetext{
${ }^{2}$ Thus Colbert created large royal forests so that, two centuries later, military ships will have sufficiently high and solid masts.
} 
the Merchant can advise of the fitting conditions, to bee insisted upon, and obtained in the point of traffike, for the advancement of his King and Countrey, which a Statesman doth not so much regard, nay many times not yet understand." (Lewes, 1641, p. 262)

Mercantilists affirm the important role of calculation in the art of control. Besides, William Petty stressed the importance of strategic information as a means of power. ${ }^{3}$

Beyond the promotion of exports, the pro-birth policy constituted another pillar of mercantilism. In France Jean Bodin outlined the advantages of an abundant population for wealth and power, with a famous sentence: "There is neither strength nor wealth but from men." Moreover a strong birth rate served the industrial and commercial interests by supplying workers. The idea of "human capital" was underlying: the training of the population, notably regarding its bravery, combativeness and education, was essential for the national power. ${ }^{4}$

Antoine de Montchrestien warned against the perverting effects of economic abundance, which could weaken the obedience and sacrifice of the population. In the same way, Thomas Mun (1664, p. 135) estimated that a nation is more "wise and industrial" if it suffers from the shortage and Josiah Child (1668, p. 20) proposed to legislate to prevent "the idleness" of the population. For Charles Davenant (1696, p. 230), the population welfare would have been greater with a limitation of foreign trade, but this one serves national power and therefore must be preserved. The objective of national power prevails over the population welfare, this latter being liable to be sacrificed to superior national interests.

John Hales (1581) considered that the development of foreign trade was necessary for the industrial development and therefore maintaining the armed forces, whereas the policy of "enclosures" had initiated a movement of massive rural migration. Foreign trade must be extended and defended, both for the state power and the population welfare. Some measures supporting the development of export industries may be justified. In this approach, wealth and power are inseparable objectives.

In fact many mercantilist authors were hostile to war, what was directly connected to their rejection of the tax system. Admittedly, taxes may be inevitable to ensure national defence in case of war, but the maintenance of peace was preferable, as expressed by Jean Bodin (1568).

"But a mighty Prince whose dominions are great and united, his Subjects many and Loyal, his Countries rich both by nature and traffique, his Victuals and warlike provisions plentiful and ready, his situation easy to offend others, and difficult to be invaded, his harbors good, his Navy strong, his alliance powerfull, and his ordinary revenues sufficient, royally to support the Majesty of his State, besides a reasonable sum which may be advanc'd to lay up yearly in treasure for future occasions: shall not all these blessings (being well ordered) enable a Prince against the suddain invasion of any mighty ennemy, without imposing those extraordinary and heavy taxes? Shall not the wealthy and loyal subjects of such a great and just Prince maintain his Honour and thier own Liberties with life and goods, always supplying the Treasure of their Soveraign, untill by a well ordered War he may inforce a happy Peace?" (Mun, 1664, p. 128)

War is only an instrument among others available for reinforcing national power. Given the cost of wars, a policy of deterrence and industrial and commercial development may appear preferable.

\section{Heterogeneous mercantilist policies}

From the 15th to the 17th century, Spain was regarded as the world greatest economic and military power in a context of unceasing wars in Europe. However, its policy of

\footnotetext{
${ }^{3}$ See Bellais (1998).

${ }^{4}$ One the contrary, for Thomas Mun and Antoine de Montchrestien, it was not desirable to reach abundance in the kingdom, as it would pervert the capacity of obedience and of sacrifice of the population.
} 
"chryshedonism" resulted in its relative decline. On the contrary, the rise of its exports on international markets, notably colonial ones, combined with protectionism transformed England in the first industrial power of the modern world. Even though both countries chose mercantilist policies, these policies were very different. Mercantilism was characterised by some great economic and philosophical principles, which justified military and economic conflicts between European states, notably due to the colonial conquest. There were several kinds of mercantilism, differing among countries and in time, but with few common principles like the importance given to the state power, the stock of precious metals and populationism. But the English, French and Spanish mercantilist principles have much differed on their main objectives.

Spanish mercantilists (in particular Ortiz, Olivarès and Botero) insisted that the sovereign needs accumulating precious metals, considered as the ground for military and economic power. The importance attached to the accumulation of gold and silver was explained by the insufficiency of credit, while the economy was gradually monetised in the 16th century. The "chryshedonism," i.e. the research of the maximum of satisfaction through gold ownership, was a determining factor in the colonial policy. It leads to a policy of "bullionism," i.e. the prohibition of gold outflows. This policy contributed to the decline of Spain, to the benefit of the industrial England. Indeed, gold inflows induced inflation that disturbed economic activity and reduced the competitiveness of Spanish products. The abundance of gold did not serve productive investments but extravagant expenditures and Spain had to face a declining trade. This effect was similar to the "Dutch disease," that is, revenues (in this case, a quasirent) may produce negative effects on an economy through an inadequate use.

For the French mercantilists, state interventionism was necessary. In response to Malestroit, Bodin (1568) developed the quantitative theory of money, according to which the value of a currency - whatever its nature - is inversely proportional to its quantity. However he did not give up the chryshedonist point of view, that is, national wealth is proportioned with the size of the treasure. Bodin considered that the true wealth of a country consisted in gold and money, and that their abundance was an advantage which largely compensates for the disadvantage of induced inflation (which also results in a fall of the interest rate favourable to the development of economic activities ${ }^{5}$ ). Most French mercantilists were opposed to the export of currency, and rather hostile to foreign trade.

For Barthélemy Laffemas, ${ }^{6}$ the trade of foreigners within the French territory was responsible for the ruin of France. Antoine de Montchrestien (1615), who created the expression of "political economy," advocated for the search of self-sufficiency. His Traité d'Economie Politique was marked by a strong nationalism and a virulent attack against foreigners, in particular the merchants, who were held responsible for all sufferings in France. The French mercantilism was thus characterised by the exacerbation of xenophobic feelings. The recommended remedies were exports duties, import restrictions and an industrial policy so as to reach self-sufficiency. Abundance, prodigality and luxury expenditures were considered as dangerous for the "greatness of France. ${ }^{77}$ However the colonial conquest was approved as a mean to extend the national territory and spread the national culture. The French mercantilism

\footnotetext{
${ }^{5}$ Bodin's analysis is not contradictory in an international monetary system founded on the gold standard. Because of states restrictions on trade, the quantitative theory applied only to the restrictive case of economic laissez-faire.

${ }^{6}$ Barthélemy Laffemas (1545-1611) was the tailor and the valet of Henri IV, then the general Controller of Trade in 1602 (Coulomb, 1998, pp. 63 et sqq.).

${ }^{7}$ It was only at the end of the 17 th century that Nicholas Barbon imposed an opposite view, according to which any trade was justified by itself.
} 
extolled the virtues of war, considered as a way to reinforce the national unity and virtue, ${ }^{8}$ and increase the public revenue.

The specificity of the French mercantilism was to insist on the industrial development. JeanBaptiste Colbert, Ministry of Louis XIV, aimed at the same time at finding the ways to finance numerous wars and thwarting the Dutch commercial rise, interpreted as an aspect of the desire for power of the Netherlands. The French economic policy was then characterised by measures to support manufactures and the exports of manufactured goods, notably with import prohibition. The state refused the export of strategic products (in particular weapons) and it already practiced a strategy of imports substitution, later theorised by Prebisch and Furtado and applied in South America after the Second World War. The French mercantilism directly links the power of the Prince with the nation ranking in the world hierarchy of wealth.

The English mercantilism (especially Davenant, Mun or Child) was quite different from the French one. It was based on the idea of a national economic development promoted through trade and the encouragement of individual initiative. It is in England that mercantilism acquired a certain theoretical legitimacy, in particular relating to the advantages of a trade surplus and weak interest rate. Trade surplus allows the constitution of a treasure (or a public saving) likely to reinforce the national development.

Some debates have taken place on the best trade policy. For Charles Davenant, there is a direct link between the change in national wealth and in foreign trade. Rather than seeking the accumulation of precious metals, the state should attempt to develop its national industries, whose exports contribute to the economic development.

A common conception in England was that the East India Company was responsible for the unfavourable trade balance, leading to currencies outflows. However this company was defended by Thomas Mun, who explained its role in substituting traditional imports for colonial trade and in acquiring essential goods, like spices or rough materials whose transformation in England provided work to a great number of employees. These arguments justified the perpetuation of the English monopoly in India, a strategic objective in the context of a sharp competition with the Netherlands, which often degenerated into open conflicts.

"The Hollanders, at this time, are very powerful in India; (...) it is undoubtedly in their power, to engross this rich traffic wholly to themselves, and to expel custom for ever from those countries. (...) Goal supposes they should off drive custom from thence by force arms, but that we should quit the trade to them through negligence and folly, it will be worth while to consider, what addition off wealth and strength year entire monopoly off East-India goods may prove to that common wealth." (Davenant, 1696, p. 236)

Later, Thomas Mun reaffirmed the need for trade surplus and advised to encourage agriculture and reduce imports. The state should guide economic activities to maximise the national wealth and productions that reinforce the policy of power.

The state must not only look after the size of national treasure; it must also encourage the production of armaments. For Thomas Mun (1664, p. 132), the treasure should be used in peacetime to reinforce the military fleet, fortifications, maintain armies or store weapons and powder. The availability of goods and techniques of production useful for defence is decisive, the power being not directly founded on gold, but on weapons.

"So that we may account that Prince as poor who can have no wares to buy at his need, as he that hath no money to buy wares; for although Treasure is said to be the sinews of the War, yet this is so because it doth provide, unite \& move the power of men, victuals, and munition where and when the cause doth require; but if these things be wanting in due time, what shall we then do with our mony?" (Mun, 1664, p. 132)

\footnotetext{
${ }^{8}$ These ideas will be taken up by the German historical school during the 19th century.
} 
In addition, the treasure should not only used for war preparedness, but also to prevent famines, in particular by stockpiling grain and other provisions. In this approach, the economy is above all in the service of the state military power.

The texts of English mercantilism shows that their authors have become more and more open to liberal ideas, considering trade as fundamental for balancing productive supply and consumption. They have therefore presented trade as essential for the increase of national wealth, in order to develop the state power.

The defence of trade by mercantilists at the end of the 17th century already announced the English Classical theory, though most of the time their praise of free trade and nations' common interests masked the defence of particular interests. Mercantilism is based on the idea that the economy is in the service of the national political power: its offensive nature is opposed to the liberal concept of peace and enrichment through free trade. Of course both liberalism and mercantilism sought at the same time enrichment and power. But the hierarchy between those two objectives has been reversed by the Classical school, which gives priority to the development of wealth in its analyses.

The development of mercantilism therefore shows a progressive transition of the economic thought towards a lower consideration of political aspects. Mercantilism presents a specific conception of the relationship between war and economy, and does not consider the possibility of a simultaneous enrichment of all nations through international trade. For Classical economists, peace should result from the progress in economic knowledge. For mercantilists, peace is not an objective, as it does not ensure the state power. Military power and economic power were merged. 


\section{References}

Bacon, F., 1625, Essays (Edition La Boétie, Bruxelles), 1945.

Bellais, R., 1998, Investissements administrés, technologie et innovation. Le cas de la production d'armements en relation avec les industries concurrentielles, Ph.D. dissertation (Université du Littoral, Dunkirk).

Bodin, J., 1568, La vie chère au XVIe siècle. Réponse de Monsieur Jean Bodin à Monsieur de Malestroit (Colin, Paris), 1932.

Child, J., 1668, Brief observations concerning trade and interest of money, in: Lars Magnusson, ed., 1994, Mercantilism: The shaping of an economic language (Routledge, London and New York), Volume 1.

Child, J., 1681, A treatise concerning the East-India trade, in: Lars Magnusson, ed., 1994, Mercantilism: The shaping of an economic language (Routledge, London and New York), Volume 2.

Child, J., 1693, A new discourse of trade, in: Lars Magnusson, ed., 1994, Mercantilism: The shaping of an economic language (Routledge, London and New York), Volume 3.

Clément, S., 1695, A discourse of the general notions of money, trade, and exchanges, as they stand in relation each to other, in: Lars Magnusson, ed., 1994, Mercantilism: The shaping of an economic language (Routledge, London and New York), Volume 3.

Coulomb, F., 1998, Les théories économiques de la guerre, de la paix et de la défense, Ph.D. dissertation (Université Pierre Mendès France, Grenoble).

Davenant, C., 1696, An essay on the East-India trade, in: Lars Magnusson, ed., 1994, Mercantilism: The shaping of an economic language (Routledge, London and New York), Volume 2.

Davenant, C., 1697, Discourse on the public revenues and on trade, in: Lars Magnusson, ed., 1994, Mercantilism: The shaping of an economic language (Routledge, London and New York), Volume 3.

Fontanel, J., 2005, La globalisation en analyse (L'Harmattan, Paris).

Hales, J., 1581, A discourse of the common weal of this Realm of England, London.

Lewes, R., 1641, The treasure of traffike, in: Lars Magnusson, ed., 1994, Mercantilism: The shaping of an economic language (Routledge, London and New York).

Locke, J., 1691, Some considerations of the consequences of the lowering of interest, and raising the value of money, in: Lars Magnusson, ed., 1994, Mercantilism: The shaping of an economic language (Routledge, London and New York), Volume 2.

Locke, J., 1696, Further considerations concerning raising the value of money, in: Lars Magnusson, ed., 1994, Mercantilism: The shaping of an economic language (Routledge, London and New York), Volume 2.

Machiavel, N., 1513, Le Prince (Flamarion, Paris), 1993.

Montchrestien de, A., 1615, Traicté de l'économie politique (Edition Plon, Nourrit et Cie, Paris), 1889.

Mun, T., 1664, English Treasure by forraign trade, in: Lars Magnusson, ed., 1994, Mercantilism: The shaping of an economic language (Routledge, London and New York), Volume 1. 